\title{
РЕГИОНАЛЬНЫЕ ОСОБЕННОСТИ ФЕДЕРАЛЬНОГО БЮДЖЕТНОГО ИНВЕСТИРОВАНИЯ
}

\author{
(c) 2021 Марков Борис Евгеньевич \\ адъюнкт кафедры экономики, бухгалтерского учета и аудита \\ Краснодарский университет МВД России, Россия, Краснодар \\ E-mail: astrapol05@gmail.com
}

Одной из наиболее приоритетных задач внутренней политики любого государства, является обеспечение равномерного социально-экономического развития территорий. Бюджетные инвестиции относятся к наиболее эффективным инструментам по преодолению регионального неравенства. Автором проведен анализ территориальных особенностей распределения федеральных бюджетных инвестиций.

Ключевые слова: региональное неравенство, федеральные бюджетные инвестиции, инвестиции в основной капитал, бюджетно-налоговая политика, устойчивость, инфраструктура, социальноэкономическое развитие.

Непропорциональность в распределении экономических ресурсов между отдельными регионами страны отрицательно влияет на устойчивость экономики и способна являться причиной различных негативных политических проявлений, вплоть до межрегиональных конфликтов и роста сепаратистских настроений.

Очевидно, что абсолютное равенство социально-экономического развития всех территорий государства - ситуация идеальная и недостижимая. Естественная тенденция к концентрации экономической деятельности в центрах деловой активности, связанная с нарушением экономического баланса между регионами наблюдается даже в развитых странах. Как правило, резкое обострение неравенства происходит в периоды активного экономического роста, либо резких политических или социальноэкономических потрясений.

Глубокое региональное неравенство - одна из самых сложных и заметных на обывательском уровне российских проблем. Разработанный в целях оценки такого неравенства и рассчитанный Всемирным Банком коэффициент региональной корреляции для Российской Федерации на 2015 год значительно превышал такие показатели всех сравнимых по экономическому статусу стран мира. По статистическому показателю ВРП на душу населения самый бедный и самый богатый субъекты федерации отличались в 17 раз [3].

K специфическим особенностям современной экономики России, отличающих её от про- чих государств, сопоставимых по политическому и экономическому масштабу относятся:

- экономическая централизация в городах федерального значения;

- сильная дифференциация уровня развития регионов;

- территориальная разобщённость отдельных социально-экономических центров, не обеспеченных в достаточной мере инфраструктурой [2].

Бюджетные инвестиции - один из наиболее доступных и эффективных инструментов налогово-бюджетной политики, направленной на преодоление регионального неравенства особенно в условиях кризисных ситуаций. Международный валютный фонд, обращаясь к проблеме преодоления последствий пандемии COVID-19, отмечает, что в ситуации, когда процентные ставки находятся на минимальных значениях, увеличение качественных государственных инвестиций может оказать мощное воздействие на занятость и экономическую активность, привлечь частные инвестиции и абсорбировать избыточные частные сбережения, не провоцируя роста стоимости заимствования [4].

Вместе с тем, территориям не следует чрезмерно полагаться на такую поддержку. Так Всемирный Банк считает важной задачей правительств - способствовать укреплению бюджетной устойчивости регионов снижая их зависимость от долгосрочных федеральных инвестиций в основной капитал и обеспечивая 
поступление собственных доходов их бюджетов, достаточных для финансирования нормативных обязательств [3].

Основное предназначение бюджетных инвестиций - приобретение (строительство, реконструкция и пр.) дорогостоящих объектов производственной, транспортной, и социальной инфраструктуры. Критерии эффективности подобных инвестиционных проектов могут не содержать упоминания о конкретных показателях прибыли, которые в обязательном порядке предусматривают бизнес-планы, однако они, в конечном счете, направлены на повышение эффективности экономики региона [1].

В целях оценки приоритетов федеральной бюджетно-налоговой политики проведен анализ и сравнительное сопоставление показателей структуры и динамики федеральных бюджетных инвестиций в основной капитал с отдельной де- тализацией по регионам ЮФО.

В абсолютных значениях наибольшие объемы федеральных бюджетных инвестиций направлены на объекты основного капитала Центрального и Южного федеральных округов (рис. 1).

Доля ЮФО в общем объеме, выделяемых в течение 2010-2019 г.г. средств изменялась в диапазоне от 10 до 27 процентов (рис. 2).

Наименьшая доля финансирования (4-6\%) традиционно выделяется промышленно развитому Уральскому федеральному округу, экономика которого более привлекательна для частных инвестиций и располагает более продвинутой промышленной инфраструктурой, вследствие чего не так остро нуждается в федеральной поддержке.

Среди регионов ЮФО в последние пять лет крупнейшие объемы федеральных инвестиций осваивались Краснодарским краем, республи-

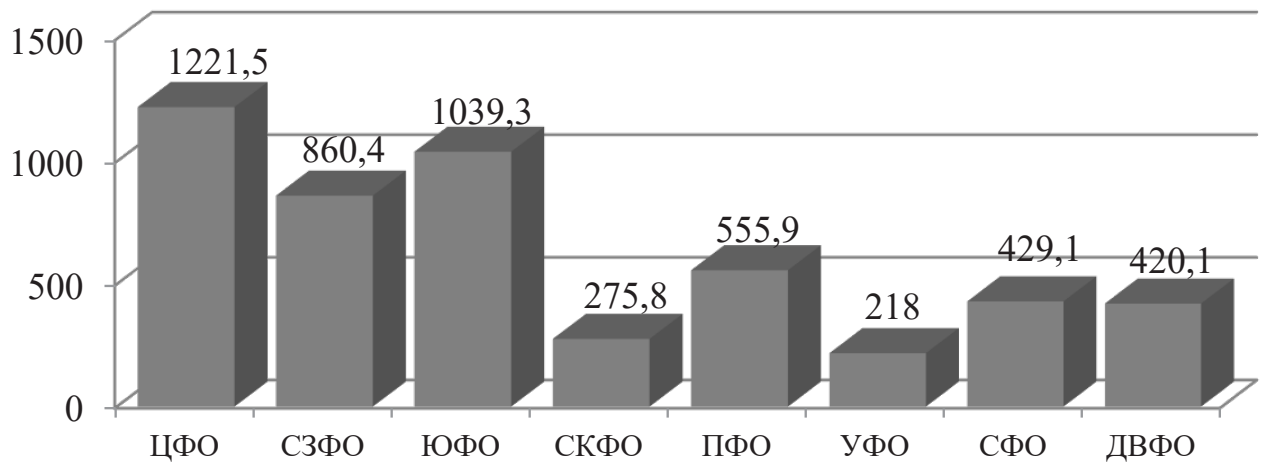

Puc. 1. Объем федеральных бюджетных инвестиций в основной капитал за 2015-2019 г.г., млрд. руб. (подготовлено по данным Росстата [6])
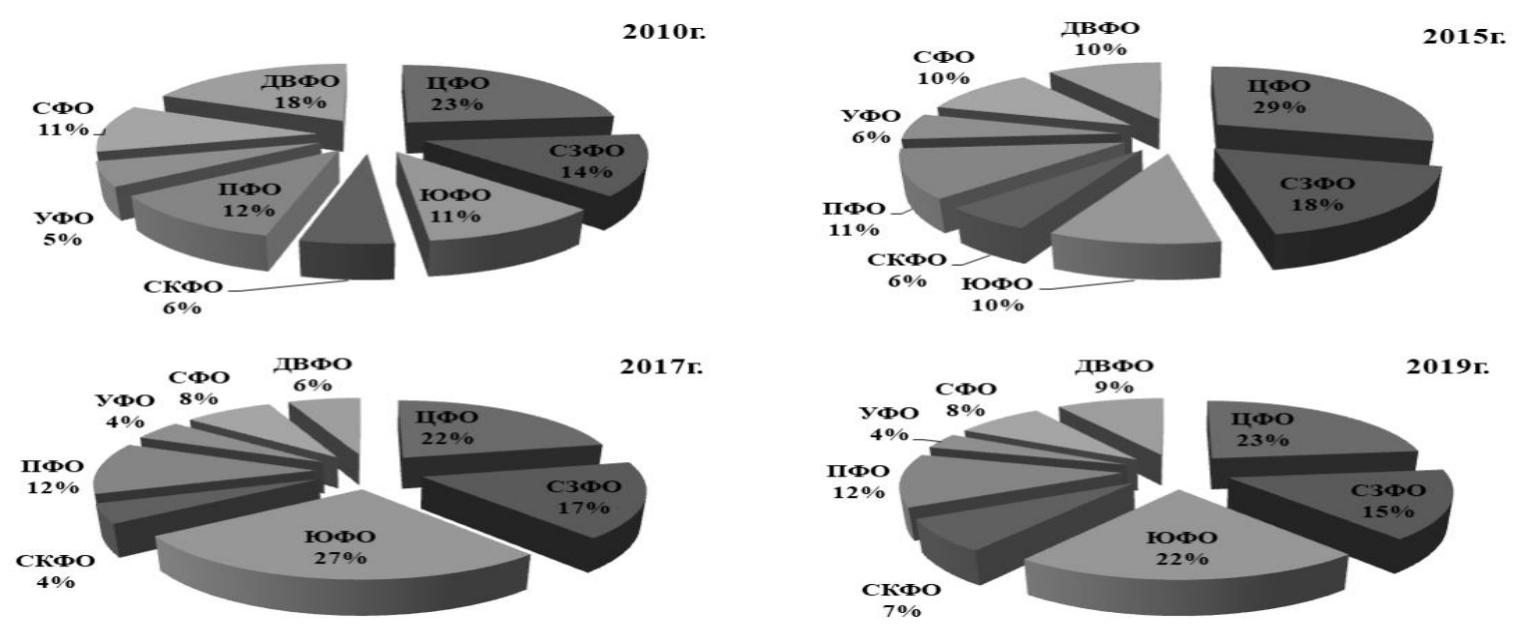

Puc. 2. Динамика распределения федеральных бюджетных инвестиций в основной капитал (подготовлено по данным Росстата [6]) 
кой Крым и Ростовской областью (рис. 3). При этом Краснодарскому краю выделено $11,2 \%$ от общероссийского финансирования, а Крымом получено 10,9\%. Наименьшие объемы средств направлены в небольшие по численности населения Астраханскую область, Адыгею и Калмыкию.

Распределение федеральных инвестиций в основной капитал между регионами ЮФО с 2010 года представлено на рисунке 4.

Последние пять лет наблюдаемого периода характеризуются постепенным сокращением доли Краснодарского края (с 45 до 22 процентов) и существенным увеличением доли Севастополя (до 11\%) и Крыма (до 42\%). Совокупно за 2015-2019 г.г. три этих субъекта получили 67,9\% от всего федерального инвестиций Южного федерального округа.
Распределения федеральных инвестиций по видам экономической деятельности также имеет свои особенности. Наиболее значительной в целом по стране является категория «Транспортировка и хранение», на финансирование которой за 2017-2019 годы было направлено 42\% средств (рис. 5). Вторым по объему финансирования является направление - «Государственное управление и обеспечение военной безопасности; социальное обеспечение» - 16,8\%. Существенные федеральные инвестиции также распределяются на здравоохранение, образование, деятельности в области культуры, спорта и досуга.

Особенностью Южного федерального округа за тот же период является значительно большая, чем в среднем по России, доля финансирования направлений «Транспортировка и хранение»

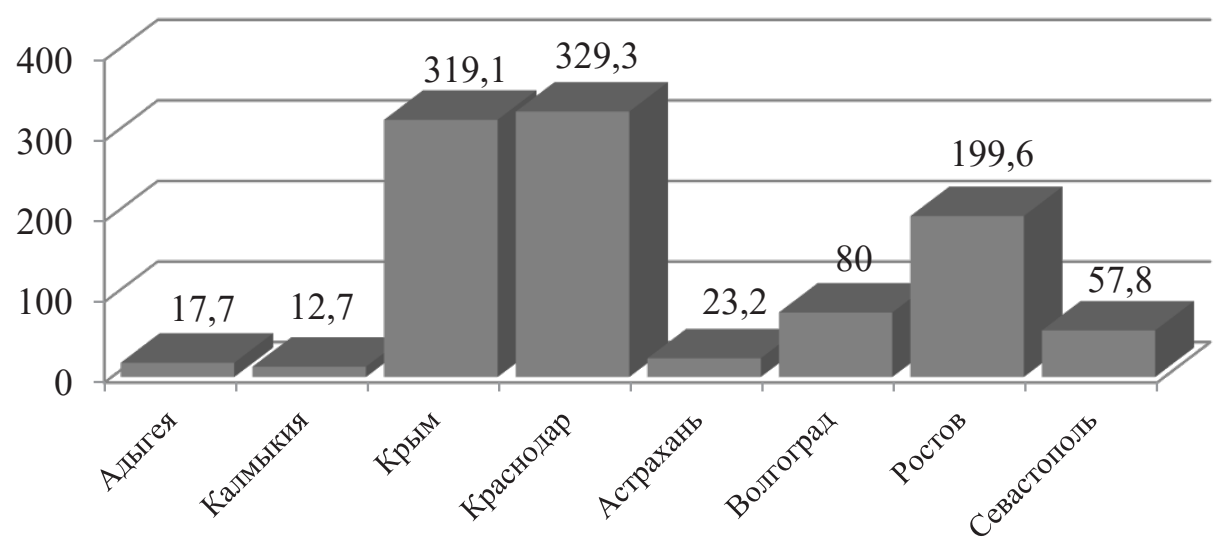

Puc. 3. Федеральные инвестиции в основной капитал по субъектам ЮФо за 2015-2019 г.г., млрд. руб. (подготовлено по данным Росстата [6])
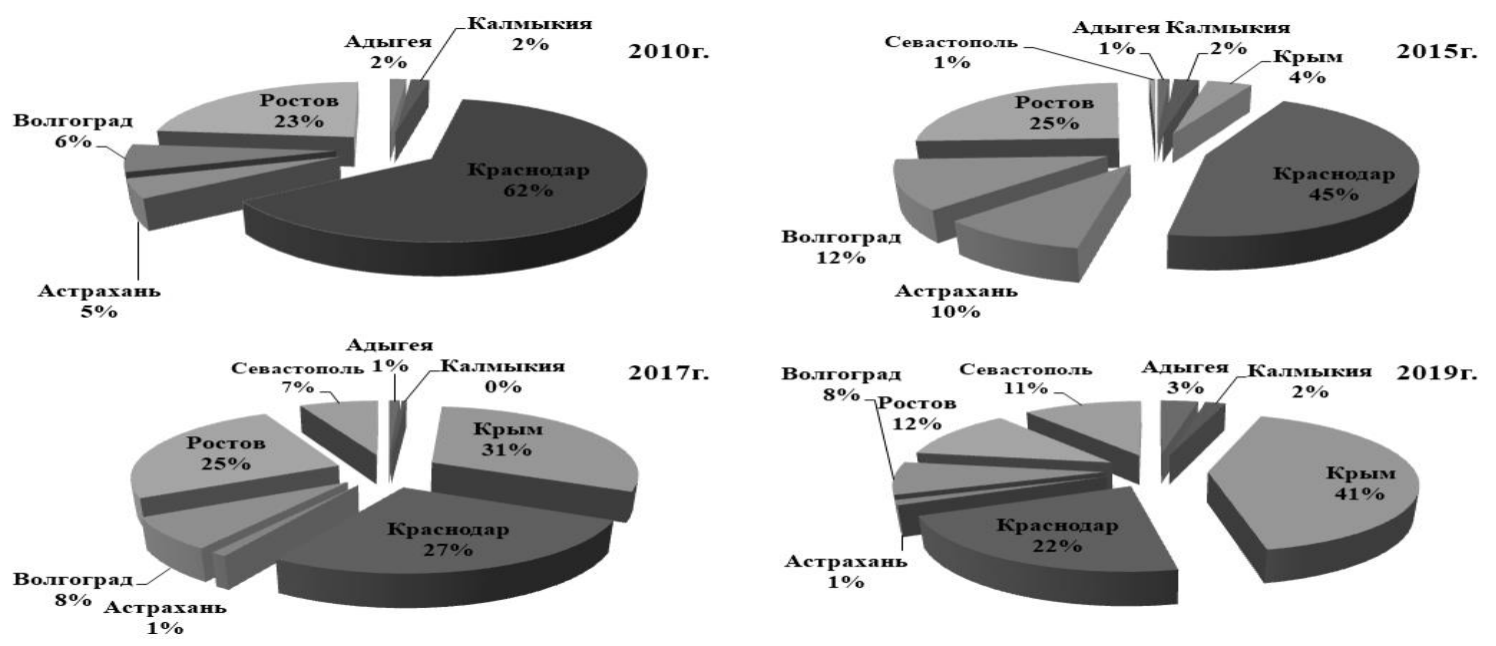

Puc. 4. Динамика распределения федеральных инвестиций в основной капитал по субъектам ЮФо (подготовлено по данным Росстата [6]) 


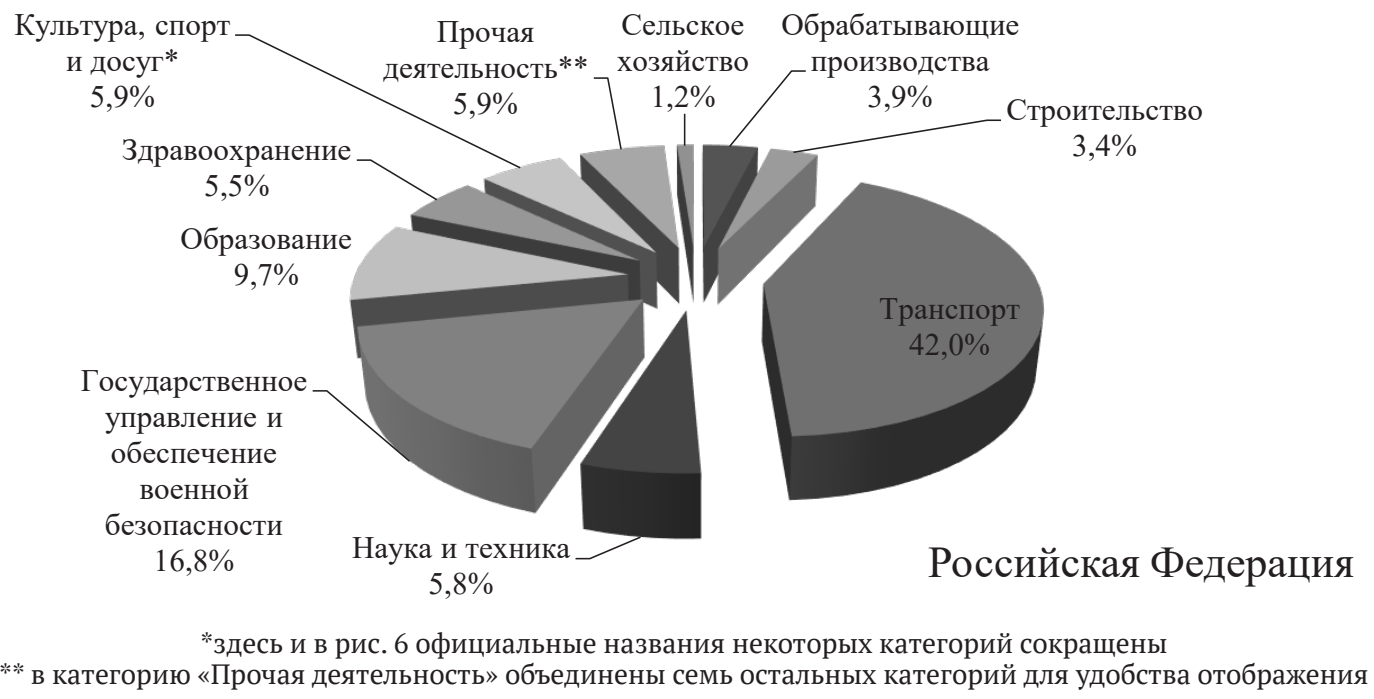

Puc. 5. Федеральные бюджетные инвестиции в основной капитал за 2017-2019 г.г. по видам экономической деятельности (подготовлено по данным Росстата [7])

$(62,5 \%)$ и «Госуправление и военная безопасность» (19,2\%). Вместе с тем, доли федеральных инвестиций расходуемых на создание объектов основного капитала профессиональной научной и технической деятельности, строительства, обрабатывающих производств, здравоохранения и образования значительно ниже среднероссийских (рис. 6).

Распределение федеральных инвестиций по видам экономической деятельности в регионах ЮФО также имеет некоторые особенности. В отличие от общероссийской и общеокружной тенденций, в Астраханской области и Севастополе в последние три года, доля инвестиций в транспорт совсем незначительна, а большая часть федеральных средств (от 43,7 до 91,2\%) поступала по категории «Госуправление и воен- ная безопасность». Совершенно другая ситуация в республике Крым и Краснодарском крае, где наоборот, финансирование инвестиций по виду деятельности «Транспортировка и хранение» составляет до $88,8 \%$ от общего объема. Наиболее значительными долями инвестиций в основной капитал сельскохозяйственной сферы выделяются республика Адыгея и Краснодарский край.

Разумеется, абсолютные показатели не могут являться достаточной базой для региональных сопоставлений. Для этих целей используем в качестве относительного показателя удельные бюджетные инвестиции, приходящиеся на количество занятых в экономике региона.

Очевидно, что основными территориальными приоритетами бюджетно-налоговой политики федерального центра являются Южный,

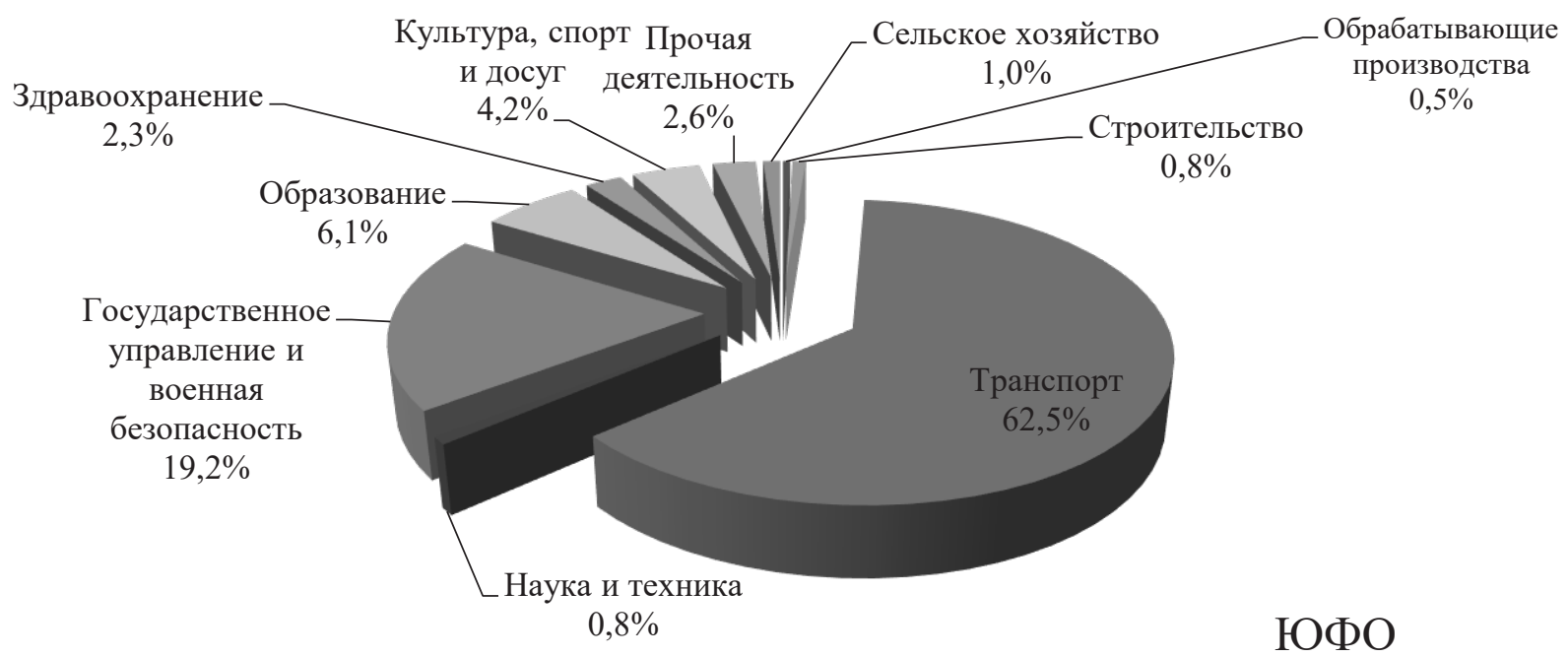

Puc. 6. Федеральные инвестиции в основной капитал за 2017-2019 г.г. по видам экономической деятельности в ЮФО (подготовлено по данным Росстата [7]) 
Дальневосточный и Северо-западный федеральные округа, где в 2019 году на каждого занятого приходится от 22,7 до 29,8 тыс. руб. федеральных инвестиций (табл. 1). Наименьшие удельные инвестиции за этот же период распределены УФО (6,1 тыс. руб.) и ПФО (8,9 тыс. руб.). Схожее региональное соотношение наблюдается на протяжении всего анализируемого периода, с 2010 года.

Между субъектами ЮФО наблюдаются существенные различия (рис. 7). Очевидно, что преобладающая позиция Южного федерального округа обеспечена за счет максимальных объемов финансирования объектов наиболее населенного Краснодарского края (свыше 34,1\% от общего числа занятых округа на 2019 год) единственного региона ЮФО, в котором показатель федеральных бюджетных инвестиций на одного занятого в экономике существенно превышал среднероссийский уровень на протяжении всего наблюдаемого 10-летнего периода. Относительные показатели федерального инвестирования распределяемого Астраханской и Волгоградской областям, почти ежегодно, значительно ниже, чем в среднем по стране.

Для оценки степени учета при применении инструментов бюджетно-налоговой политики состояния инвестиционной привлекательности территорий представляет интерес изучение соотношения удельных инвестиций из федераль-

Таблица 1. Удельные федеральные бюджетные инвестиции на одного занятого в экономике, тыс. руб. (рассчитано по данным Росстата [6,8])

\begin{tabular}{|l|c|c|c|c|c|c|}
\hline \multirow{2}{*}{ Территория } & \multicolumn{3}{|c|}{ Годы } & \begin{tabular}{c} 
Темп \\
прироста \\
\cline { 2 - 7 }
\end{tabular} \\
\cline { 2 - 7 } & 2010 & 2013 & 2015 & 2017 & 2019 & 55,8 \\
\hline Россия & 9,5 & 13 & 13,8 & 13,8 & 14,8 & 50,6 \\
\hline ЦФО & 7,9 & 12,1 & 14,1 & 10,4 & 11,9 & 81,6 \\
\hline СЗФО & 12,5 & 13,2 & 24,8 & 23,3 & 22,7 & 156,9 \\
\hline ЮФО & 11,6 & 26,2 & 13,7 & 34,8 & 29,8 & 81,0 \\
\hline СКФО & 10,5 & 14 & 13,9 & 10,6 & 19 & 71,2 \\
\hline ПФО & 5,2 & 8,1 & 7,4 & 7,9 & 8,9 & 1,7 \\
\hline УФО & 6 & 5,8 & 9,6 & 7,3 & 6,1 & 20,9 \\
\hline СФО & 8,6 & 8,5 & 12,7 & 9,7 & 10,4 & $-15,7$ \\
\hline ДВФО & 30,0 & 33,4 & 24,8 & 15,7 & 25,3 & 2 \\
\hline
\end{tabular}

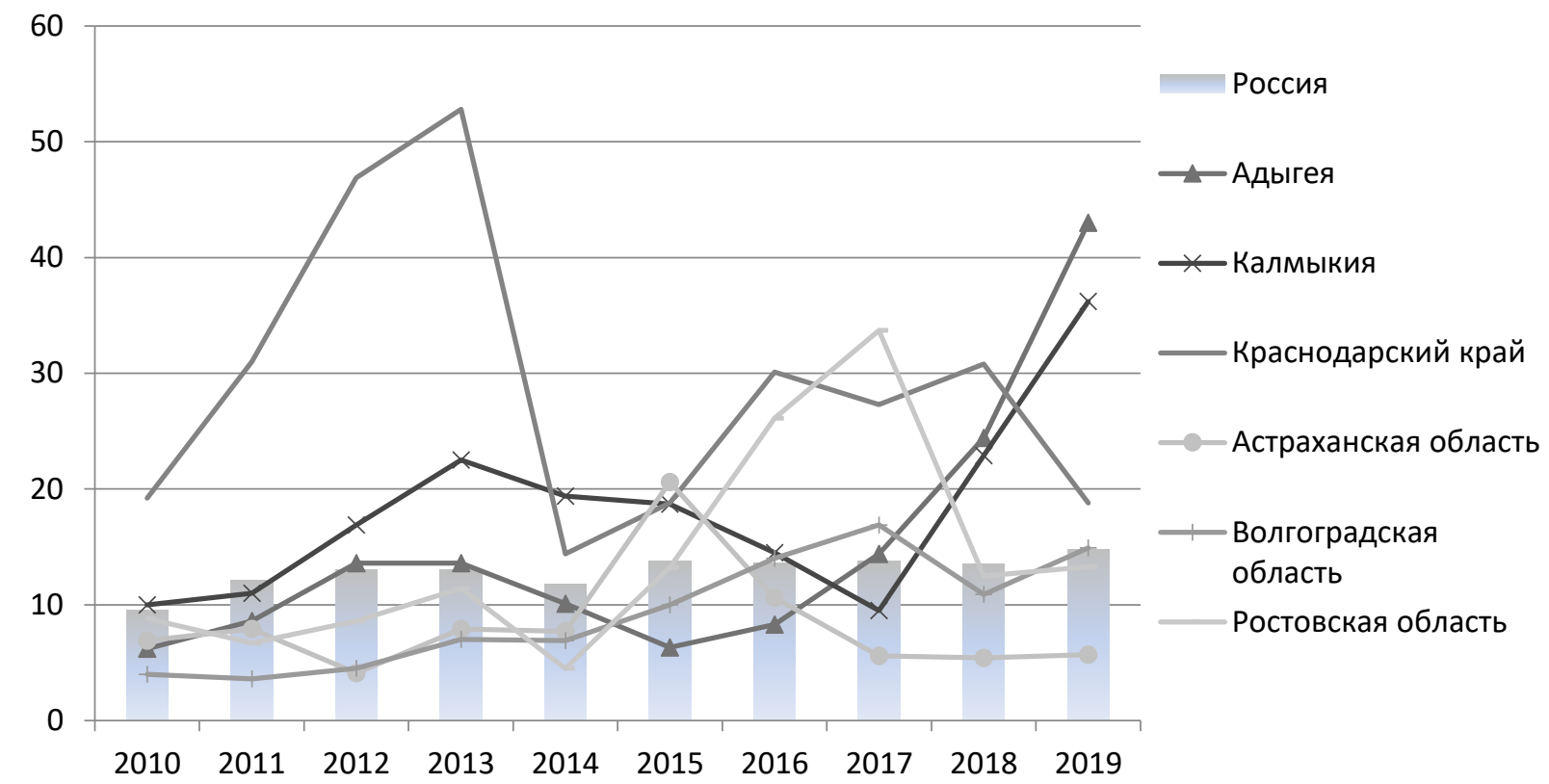

Puc. 7. Удельные федеральные бюджетные инвестиции в основной капитал на одного занятого в экономике, тыс. руб. (подготовлено по данным Росстата $[6,8]$ ) 
ного бюжета и из остальных источников (нефедеральных) в расчете на одного занятого (рис. 8). Данные в целом свидетельствуют о внимании федерального центра к вопросу урегулирования регионального неравенства в инвестиционной привлекательности. В округа с низкими относительными показателями нефедеральных инвестиций распределяются повышенные объемы федеральных. Если в среднем по стране за 2019 год соотношение между удельными федеральными и нефедеральными инвестициями в основной капитал составило $1: 12,8$, то в ЮФО на рубль федеральных инвестиций на одного занятого приходится всего 3 рубля инвестиций из прочих источников, а в СКФО - всего 2,2 рубля. Для сравнения - наиболее индустриально развитому Уральскому федеральному округу, промышленность и социальная сфера которого привлекли на каждого занятого 420,5 тыс. руб. нефедеральных инвестиций, федеральный центр дополнительно направил только 6,1 тыс. руб. (соотношение $-1: 69$ ).

На уровне регионов ЮФО наблюдается аналогичная ситуация. Менее всего за 2019 г. федеральный центр участвует в инвестировании в основной капитал в Астраханской области, показавшей максимальные параметры по при- влечению инвестиций из прочих источников в округе - соотношение относительных показателей - 1:29,5. В наибольшей степени финансировалась республика Калмыкия, где данное соотношение составило лишь 1 к 1,9 (рис. 9). Подобный принцип прослеживается на протяжении всего наблюдаемого периода с 2010 года.

Приведенные данные позволяют оценить территориальные приоритеты федеральной бюджетно-налоговой политики в части применения такого инструмента, как бюджетные инвестиции.

В течение наблюдаемого периода (20102019 г.г.) Южный федеральный округ являлся одним из главных направлений федерального бюджетного инвестирования в основной капитал, как в абсолютном, так и в относительном (в расчете на одного занятого в экономике) измерении.

Однако, результаты такого особого отношения не достаточно отразились на экономических показателях (табл. 2). За 2019год один занятый в экономике регионов ЮФО в среднем создал 855,9 тыс. руб. ВРП, что на 35,2\% ниже среднего показателя по России. Динамика также ниже среднероссийской. Для сравнения - в 2010 году разрыв в показателях составлял 32,6\%.
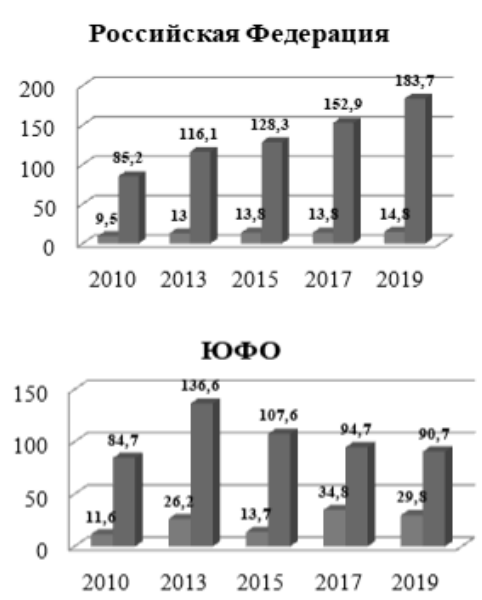

УФО

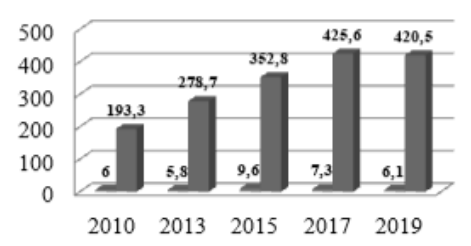

ЦФО

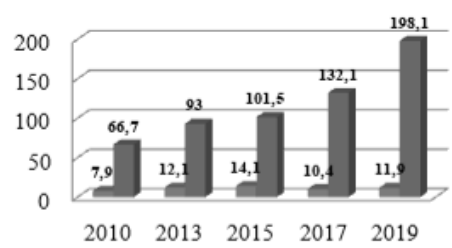

СКФО
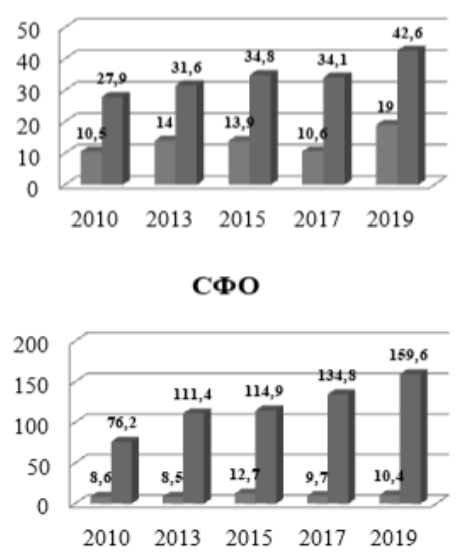

СЗФо

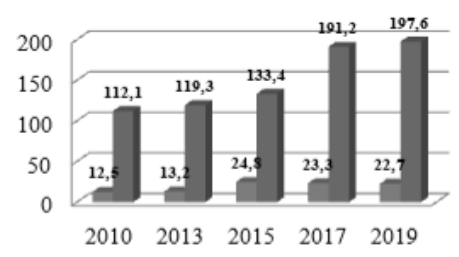

ПФО

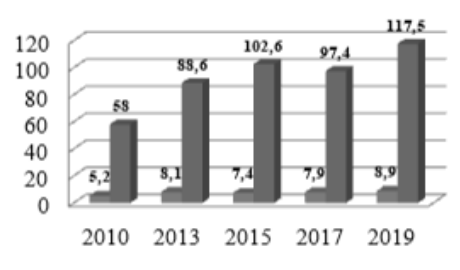

ДВФО

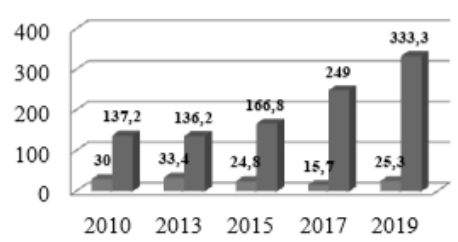

- Федеральные = Нефедеральные

Puc. 8. Соотношение источников инвестиций в расчете на одного занятого по федеральным округам, тыс. руб. (подготовлено по данным Росстата [6]) 
Адыгея

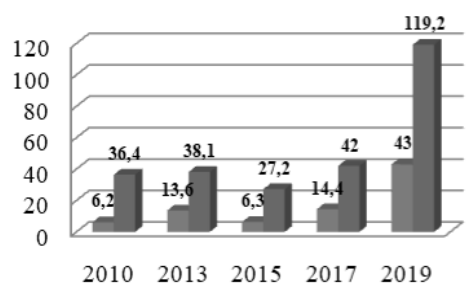

Астраханская область

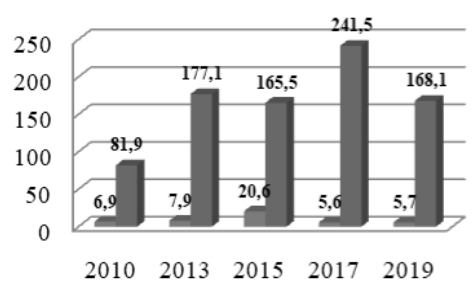

Калмыкия

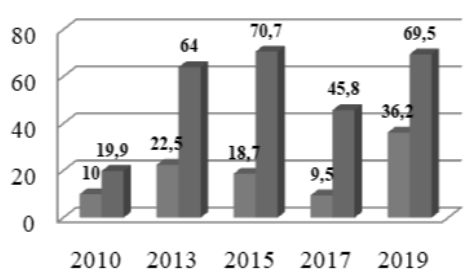

Волгоградская область

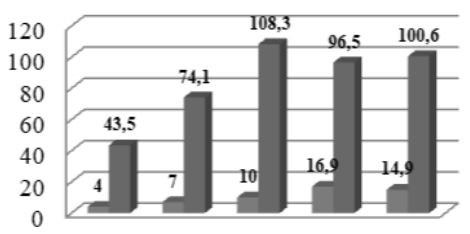

$2010 \quad 2013 \quad 2015 \quad 2017 \quad 2019$
Краснодарский край

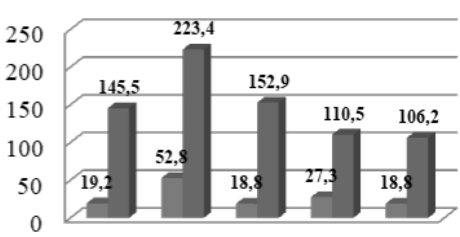

$2010 \quad 2013 \quad 2015 \quad 2017 \quad 2019$

Ростовская область

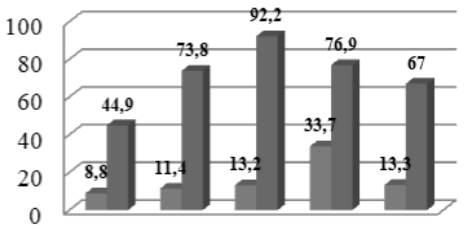

$2010 \quad 2013 \quad 2015 \quad 2017 \quad 2019$

Ф Федеральные " Нефедеральные

Puc. 9. Соотношение источников инвестиций в расчете на одного занятого по субъектам ЮФо, тыс. руб. (подготовлено по данным Росстат [6])

Таблица 2. Динамика ВРП в расчете на одного занятого в экономике субъектов ЮФО, тыс. руб. (рассчитано по данным Росстата [8,9])

\begin{tabular}{|l|c|c|c|c|c|c|}
\hline \multirow{2}{*}{\multicolumn{1}{c|}{ Территория }} & \multicolumn{3}{c|}{ Годы } & Прирост \\
\cline { 2 - 6 } & 2010 & 2013 & 2015 & 2017 & 2019 & $19010, \%$ \\
\hline Россия & 538,9 & 757,8 & 909,1 & 1036,8 & 1321,1 & 145,1 \\
\hline ЮФО & 363,1 & 546,7 & 607,3 & 697,9 & 855,9 & 135,7 \\
\hline Республика Адыгея & 254,1 & 366,3 & 458 & 544,6 & 718,2 & 182,6 \\
\hline Республика Калмыкия & 192,7 & 330,9 & 402,4 & 527,4 & 738,9 & 283,4 \\
\hline Краснодарский край & 423,2 & 676,1 & 761,4 & 849,9 & 955,3 & 125,7 \\
\hline Астраханская область & 300,5 & 553,7 & 658,2 & 849,5 & 1287,6 & 328,5 \\
\hline Волгоградская область & 355,6 & 483,4 & 610,3 & 646,5 & 819,1 & 130,3 \\
\hline Ростовская область & 330,6 & 456,8 & 594,2 & 667,5 & 822 & 148,6 \\
\hline
\end{tabular}

Среди южных регионов крупнейшие объемы федеральных инвестиций в основной капитал осваиваются Краснодарским краем, однако темп прироста относительного показателя ВРП здесь самый низкий в округе $-125,7 \%$. Из субъектов ЮФО только Астраханская область имеет по
2019 году показатели, сопоставимые со среднероссийскими - 1287,6 тыс. руб. на одного занятого. Этот регион также добился максимальной динамики за десятилетие - рост на $328,5 \%$. при наименьших объемах федерального инвестирования.

\section{Библиографический список}

1. Маслова Д. В. Влияние бюджетно-налоговой политики на социально-экономическое положение южных регионов России // Финансы и кредит. 2016. № 37 (709).

2. Савельева И.П., Цало И. М. Методический подход к анализу и прогнозированию региональных процессов с учетом перспективного влияния изменений мировой экономики // Вестник ЮУрГУ: Экономика и менеджмент. 2012. № 44 (303) - С. 44-48 
3. The World Bank, 2018. Преодоление пространственного неравенства. Как снова собрать советский «пазл» в условиях рыночной экономики. URL: openknowledge.worldbank.org/

4. IMF Fiscal Monitor: Policies for the Recovery. October 2020. URL: https:/www.imf.org/en/Publications/ FM/ Issues/2020/09/30/october-2020-fiscal-monitor

5. URL: https://rosstat.gov.ru/storage/mediabank/met-ok.pdf

6. URL: https://www.fedstat.ru/indicator/33401

7. URL: https://www.fedstat.ru/indicator/58991

8. URL: https://www.fedstat.ru/indicator/33644

9. URL: https://gks.ru/bgd/regl/b19_14p/Main.htm 